\title{
A study of hypertension and its risk factors among females of reproductive age group
}

\author{
Borah Debajani', Deka $R^{2}$ \\ Received on October 10, 2017; editorial approval on December 20, 2018
}

\begin{abstract}
Background: The prevalence of hypertension has increased over the last decade. The lifetime risk of becoming hypertensive in industrialized countries was estimated to exceed 90\%. Objectives: To assess the association of hypertension and its risk factors among female of reproductive age group of Guwahati, Assam. Materials and methods: The present study is a cross-sectional study carried out in urban areas of Guwahati city among women of reproductive age group. Among the study population of 100, a predesigned and pre-tested interview schedule was used to record the sociodemographic and risk factors of hypertension, height, weight and blood pressure of participants. Descriptive and inferential statistics was used to find out the association of hypertension with the selected risk factors. Results: The percentage of prehypertensive was $60 \%$, stage- 1 hypertensive was 24 , and stage-2 hypertensive was $2 \%$. There was a significant association of hypertension with overweight, physical activity, socio-economic status, and intake of extra-salt in diet. Conclusion: The prevention and control of hypertension is a major concern because it is a major modifiable risk factor for coronary artery diseases and stroke. It is also necessary to control the B.P as early as possible to prevent end organ damage. The warning remains stark. The problem already extends far beyond the capacity of the developing countries to cope.
\end{abstract}

Keywords: BMI; socio-economic status; physical activity.

\section{INTRODUCTION}

Hypertension contributes to the burden of heart disease, stroke and kidney failure and premature mortality and disability. It disproportionately affects populations in lowand middle-income countries where health systems are weak. Hypertension rarely causes symptoms in the early stages and many people go undiagnosed. Those who are diagnosed may not have access to treatment and may not be able to successfully control their illness over the long term. There are significant health and economic gains attached to early detection, adequate treatment and good control of hypertension. Treating the complications of hypertension entails costly interventions such as cardiac bypass surgery, carotid artery surgery and dialysis, draining individual and government budgets. Addressing behavioral risk factors, e.g., unhealthy diet, harmful use of alcohol and physical inactivity, can prevent hypertension. Tobacco use increases the risk of complications of hypertension. If no action is taken to reduce exposure to these factors, cardiovascular disease incidence, including hypertension, will increase. Salt reduction initiatives can make a major contribution to prevention and control of high blood pressure. ${ }^{1}$

The Global Burden of Disease study has reported HTN as the 4th contributor to premature death in developed countries and the 7 th in the developing countries. ${ }^{2}$ Analysis of worldwide data on global burden of HTN showed an overall prevalence of $26.4 \%$ among the adult population in $2000 .{ }^{3}$ In India, the prevalence of HTN ranges between $20 \%-40 \%$ in urban areas and $12 \%-17 \%$ among rural adults. ${ }^{4}$

Raised blood pressure is estimated to cause 7.5 million deaths,
Address for correspondence:
${ }^{1}$ Superintendent cum Principal (Corresponding Author)
School of Nursing, Oil India Hospital-Duliajan
Email: debajaniborahdutta84@yahoo.in
Mobile: +919435980195
${ }^{2}$ Associate Professor of Anatomy, Gauhati Medical College, Guwahati-32
Email: rupsekhar@yahoo.com
Mobile: +919435196276 
about $12.8 \%$ of all deaths. It is a major risk factor for cardiovascular disease. The prevalence of raised blood pressure is similar across all income groups, though it is generally lowest in high-income populations. ${ }^{5}$ The rise of NCDs among younger populations may jeopardize many countries "demographic dividend," including the economic benefits expected to be generated during the period when a relatively larger part of the population is of working age. Instead, these countries will have to contend with the costs associated with populations that are living with longer episodes of ill health. A growing number of young adults are being affected, prompting the conclusion that the country could lose the next generation to chronic disease. ${ }^{6}$ Attempts to "treat the way out" of NCDs will not be affordable for most middleand low-income countries. Action should be oriented toward curbing the NCD risk factors and promoting healthier lifestyles to reduce NCD incidence rates and push back the age of NCD onset. ${ }^{7}$

Assam being culturally diverse state differences may be noted in different communities which may be attributable to their differences in their habits. The purpose of this study is to identify the major risk factors for hypertension. As the disease burden has also shifted from the older age group to the more productive middle age group. The study has been carried out among the females of reproductive age group.

This paper has aimed to assess the prevalence of hypertension and its risk factors among female of reproductive age group of Guwahati, Assam.

\section{MATERIALSAND METHODS}

The study is a descriptive cross-sectional study carried out in selected urban areas of Guwahati city, Assam. 100 women in the age group of 20-49 years of age who are not taking anti-hypertensive drugs and who are not actually ill were selected by random sampling methods. Pregnant and lactating mother up to the age of 12 weeks were excluded from the study.

A semi structured interview schedule was used to collect information from the subjects such as socio-demographic data, risk factors. Blood pressure for each participant was measured as per AHA guidelines. ${ }^{8}$ Classification of hypertension was done based on JNC VII criteria. ${ }^{9}$ Clients BMI was calculated by using the formulae $\mathrm{Wt}(\mathrm{kg}) / \mathrm{Ht}\left(\mathrm{m}^{2}\right)$, i.e., Quetelet's index. W.H.O Asian BMI classification was used to classify women according to their $\mathrm{BMI}^{10}$ Descriptive and inferential statistics was used to find out the association of hypertension with the selected risk factors. Selected variables are age, occupation, socio-economic status, caste, socio-economic status, obesity, physical activity, dietary pattern, intake of extra salt in diet. $\mathrm{P}<0.05$ was taken as significant.

\section{RESULTS}

In the study population, $40 \%$ are in the age group of $20-29$, $48 \%$ participants are in the age group of 30 to 39 years and $12 \%$ are in the age group of $40-49$. The percentage of prehypertensive was $60 \%$, stage -1 hypertension was $24 \%$ and stage- 2 hypertension was $2 \%$ respectively. $52 \%$ are having their BMI in the normal range and $36 \%$ are overweight and $12 \%$ are obese. Majority (90\%) of participants were Hindu. $42 \%$ of participants were either graduates or post-graduates. $94 \%$ of the participants are unemployed. Based on Kuppuswamy's socioeconomic status scale majority (92\%) of the participants are from upper middle class. $50 \%$ are having their BMI in the normal range and $36 \%$ are overweight and $12 \%$ are obese.

Table 1 Mean blood pressure level according to age, prevalence of hypertension and isolated systolic hypertension $(\mathrm{n}=100)$

\begin{tabular}{|l|c|c|c|c|c|c|}
\hline $\begin{array}{c}\text { Age Group } \\
\text { In } \\
\text { years }\end{array}$ & Frequency & Mean & SD & \multicolumn{2}{|c|}{$\begin{array}{c}\text { Hypertensive } \\
\text { Cases }\end{array}$} & \multicolumn{2}{|c|}{$\begin{array}{c}\text { Isolated systolic } \\
\text { hypertensive cases }\end{array}$} \\
\hline $20-29$ & 40 & 118.800 & 10.787 & 6 & Stage-1 & Stage-2 \\
\hline $30-39$ & 48 & 125.416 & 14.440 & 18 & 6 & 0 \\
\hline $40-49$ & 12 & 125.000 & 7.974 & 2 & 2 & 0 \\
\hline
\end{tabular}

Table 2 Physical activity (as measured by IPAQ) and hypertension $n=100$

\begin{tabular}{|l|c|c|c|c|c|c|}
\hline \multirow{2}{*}{ HIN } & \multicolumn{3}{|c|}{$\begin{array}{c}\text { Level of Physical } \\
\text { Activity }\end{array}$} & \multirow{2}{*}{ Total } & \multirow{2}{*}{ Chi Sq. } & \multirow{2}{*}{ df } \\
\cline { 2 - 5 } & High & Low & Medium & & & \\
\hline Normal & 6 & 2 & 6 & 14 & 25.185 & 4 \\
\hline Pre-hypertensive & 4 & 6 & 50 & 60 & & \\
\hline Hypertensive & 2 & 10 & 14 & 26 & & \\
\hline Total & 12 & 18 & 70 & 100 & & \multicolumn{2}{|c|}{$x^{2}=13.277$ at $d f=4, p<0.01$} \\
\hline
\end{tabular}


There is significant association of level of physical activity as measured by International Physical Activity Questionnaire and hypertension as measured by sphygmomanometer among women of reproductive age group of Guwahati at 0.01 level of significance.

Table 3 Association of selected factors and hypertension $n=100$

\begin{tabular}{|c|c|c|c|c|c|}
\hline $\begin{array}{l}\text { Sl. } \\
\text { No }\end{array}$ & Selected Factors: & Hypertensive & $\begin{array}{l}\text { Non- } \\
\text { hypertensive }\end{array}$ & Total & $\begin{array}{ll}\text { Chi } & \text { square } \\
\text { Value }\end{array}$ \\
\hline \multirow[t]{4}{*}{1} & Age in years & & & & \multirow{4}{*}{3.610} \\
\hline & Up to 30 years & 10 & 38 & 48 & \\
\hline & $>30$ years & 16 & 26 & 52 & \\
\hline & Total & 26 & 74 & 100 & \\
\hline \multirow[t]{4}{*}{2} & Occupation & & & & \multirow{4}{*}{0.003} \\
\hline & Housewife & 24 & 70 & 94 & \\
\hline & Working lady & 2 & 4 & 6 & \\
\hline & TOTAL & 26 & 74 & 100 & \\
\hline \multirow[t]{4}{*}{3} & Family History & & & & \multirow{4}{*}{4.082} \\
\hline & Present & 6 & 6 & 12 & \\
\hline & Absent & 20 & 68 & 88 & \\
\hline & Total & 26 & 74 & 100 & \\
\hline \multirow[t]{3}{*}{4} & $\mathbf{B M I}<\mathbf{3 0}$ & 22 & 66 & 88 & \multirow{3}{*}{0.071} \\
\hline & BMI $>=\mathbf{3 0}$ & 4 & 8 & 12 & \\
\hline & Total & 26 & 74 & 100 & \\
\hline \multirow[t]{3}{*}{5} & Uses extra salt & 20 & 20 & 40 & \multirow{3}{*}{19.958} \\
\hline & Does not use extra salt & 6 & 54 & 60 & \\
\hline & Total & 26 & 74 & 100 & \\
\hline \multirow[t]{3}{*}{6} & Vegetarian & 10 & 58 & 68 & \multirow{3}{*}{14.088} \\
\hline & Non-vegetarian & 16 & 16 & 32 & \\
\hline & Total & 26 & 74 & 100 & \\
\hline
\end{tabular}

$\chi^{2}=3.841$ at $\mathrm{df}=1, \mathrm{p}<0.05,2=6.635$ at $\mathrm{df}=1, \mathrm{p}<0.01$

There is significant association of presence of family history of hypertension and hypertension as measured by sphygmomanometer among women of reproductive age group of Guwahati at 0.05 level of significance.

There is significant association of use of extra salt in meals and hypertension as measured by sphygmomanometer among women of reproductive age group of Guwahati at 0.01 level of significance.

There is also significant association of dietary pattern (vegetarian or non-vegetarian) and hypertension as measured by sphygmomanometer among women of reproductive age group of Guwahati at 0.01 level of significance.

\section{DISCUSSION}

The Indian health system is challenged with major noncommunicable diseases and hypertension is the major among them. The study was carried out in urban areas of Guwahati. This is comparable with the findings of the study conducted by Madhumitha $\mathrm{M}$ et al 2014. ${ }^{11}$ Prevalence of hypertension was found to be $37.6 \%$ in Raichur district of North Karnataka. Prevalence of hypertension was significantly associated with 
smoking, fruits and vegetables intake, salt intake, junk foods, family history of hypertension and obesity. There is no significant association between prevalence of hypertension and type of diet (vegetarian or non-vegetarian), alcohol intake and physical activity. ${ }^{11}$

As per the study done by NK Bansal \& N Goswami 2014, the prevalence of pre-hypertension was found to be $32.41 \%$ $(n=294)$ among 18-35 years UG and PG students in Guwahati. A significantly higher prevalence of prehypertension was found in individuals with increasing age $(\mathrm{p}=0.008)$, family history of hypertension $(\mathrm{p}<0.00001)$, overweight/obesity $(\mathrm{p}<0.00001)$, central obesity $(\mathrm{p}<0.001)$ and physical inactivity $(\mathrm{p}<0.001)$. The most prevalent risk factor among the pre-hypertensive individuals was family history of hypertension $(70.4 \%)$, followed by overweight/ obesity $(65.6 \%)$, central obesity (51\%) and physical inactivity $(27.6 \%) .^{12}$

According to this study, significant association was seen between hypertension and level of physical activity, presence of family history of hypertension, use of extra salt and dietary pattern of women of reproductive age group of Guwahati city. The percentage of pre-hypertensive was $60 \%$, stage -1 hypertension was $24 \%$ and stage- 2 hypertension was $2 \%$ respectively in the present study.

Over all prevalence of hypertension among tea garden workers of Assam was $60.8 \%$. There were more women with hypertension i.e., $62.2 \%$ than men i.e. $59.4 \%$ although this difference was not statistically significant. ${ }^{13}$ The overall prevalence of hypertension in native rural population of Assam was $33.3 \%$ i.e., $33.2 \%$ in male and $33.4 \%$ in female. ${ }^{14}$

\section{Conclusion and recommendation}

Hypertension is a growing problem among the women of reproductive age group with pre-hypertensive $60 \%$, stage -1 hypertension $24 \%$ and stage- 2 hypertension $2 \%$ respectively in the present study. Use of extra salt in the diet, nonvegetarian diet, decreased physical activity and having family history of hypertension are the major risk factors of hypertension among women of reproductive age group of Assam.

Acknowledgement: I acknowledge the support of Dr. D. Goswami, Prof. of Medicine, GMC, Dr. G. Saikia, Joint Director of Health Service, Kamrup Metropolitan District, Mrs. V. Sugirtha, Ex-Principal, Army Institute of NursingGuwahati for their support in carrying out the study.

Ethical clearance: Taken.

Conflict of Interest: Not declared.

Source of funding: None declared.

Contribution of Authors: We declare that this work was done by the authors named in this article and all the liabilities pertaining to claims relating to the content of this article will be borne by the authors.

\section{REFERENCE}

1. World Health Organization. A global brief on hypertension - silent killer, global public health crisis released on World Health Day [Online]. 2013. [cited 2017 May 31]; Available from: URL:http://ishworld.com/ downloads/pdf/global_brief_hypertension.pdf

2. Deepa R, Shanthirani CS, Pradeepa R, Mohan V. Is the 'rule of halves' in hypertension still valid? evidence from the Chennai urban population study. J of Association of Physicians of India 2003 Jan 1;51:153-7.

3. Kearney PM, Whelton M, Reynolds K, Muntner P, Whelton PK, He J. Global burden of hypertension: analysis of worldwide data. The Lancet 2004 Jan;22(1):11-9.

4. Reddy KS, Shah B, Varghese C, Ramadoss A. Responding to the threat of chronic diseases in India. The Lancet 2005 Nov 12;366(9498):1744-9.

5. World Health Organisation [Online]. Global status report on non-communicable diseases 2010. [cited 2017 May 31]; Available from: URL:https://www.who.int/nmh/ publications/ncd_report2010/en/

6. Meno R, Frogner B. What underlies Ukraine's mortality crisis? (English). Health and demography. Washington, DC 2010: World Bank Group. [cited 2017 May 31]; Available from: URL:http://documents.worldbank.org/ curated/en/281511468143401258/What-underliesUkraines-mortality-crisis

7. Adeyi O, Smith O, Robles S. Public Policy and the Challenge of Chronic Non-Communicable Diseases. Washington, DC: World Bank; 2007. [cited 2017 May 31]; Available from: URL:http:// siteresources.worldbank.org/INTPH/Resources/ PublicPolicyandNCDsWorldBank2007FullReport.pdf

8. Smith L. New AHA recommendations for blood pressure measurement. American Family Physician. 2005 Oct 1;72(7):1391-8.

9. Chobanian AV, Bakris GL, Black HR, Cushman WC, Green LA, Izzo JL Jr et al. The Seventh report of the Joint National Committee on prevention, detection, evaluation, and treatment of high blood pressure: the JNC 7 report. J of American Medical Association. 2003 May 21;289(19):2560-72.

10. Park K. Preventive and Social Medicine. Jabalpur: M/s Bannarasidas Bhanot; 2013. p. 369.

11. Madhumitha M, Naraintran S, Manohar C, Revathi S, Mallikarjun KB, Patil RS. Hypertension - prevalence and risk factors among urban population in north karnataka. IJCRR 2014;6(7):39-45.

12. Bansal NK, Goswami N. A study to evaluate the prevalence of pre-hypertension in students of health institutions (Medical, Dental and Nursing) of Guwahati. $\mathrm{J}$ of Associations of Physicians of India 2015 Feb;63.

13. Hazarika NC, Biswas D, Narain K, Kalita HC, Mahanta J. Hypertension and its risk factors in tea garden workers of Assam. The National Medical J of India 2002 MarApr;15(2):63-8.

14. Hazarika NC, Biswas D, Narain K, Kalita HC, Mahanta J. Hypertension in the native rural population of Assam. The National Medical J of India 2004 NovDec;17(6):300-4. 